\title{
Knowledge management processes in practice: Empirical insights from the public sector
}

\author{
Nina Helander \\ Tampere University \\ nina.helander@tuni.fi
}

\author{
Annamaija Paunu \\ Tampere University \\ annamaija.paunu@tuni.fi
}

\author{
Pasi Hellsten \\ Tampere University \\ pasi.hellsten@tuni.fi
}

\begin{abstract}
Knowledge management can be regarded as a holistic and systematic process that integrates technology and human aspects to enable organizations to achieve their goals. Knowledge management promises many benefits both for the private and public sector organizations when operationalized successfully. In the context of public sector, it is possible - at least in theory - to make more informed decisions, to serve the citizens better and to use resources more effectively through knowledge management. Thus, it is not a surprise that many public organizations have started to develop their knowledge management processes. However, knowledge management faces in practice plenty of challenges in the context of public sector. The aim of this paper is to empirically study the challenges that public organizations face at different stages of the knowledge management process. Furthermore, the paper also aims to identify the enabling factors for successful knowledge management process. To better understand both the challenges and the enablers, we have carried out empirical study that is comprised of five cases from the Finnish public sector.
\end{abstract}

\section{Introduction}

Knowledge management can be regarded as a key issue in the knowledge-based economy [1] as it allows to support organizations in problem solving, decision making, and strategic planning [2]. The starting point for knowledge management is creation and access to knowledge in such a way that it is available as expediently as possible to utilize e.g. in decision-making, innovation management and organizational development [3]. This requires a functioning infrastructure and technology to succeed but especially the people's attitudes, skills and practices play a very important role [4]. Knowledge management is thus a holistic and systematic proces $s$ that integrates technology and human aspects, enabling genuine dialogue in the management of organizations [5].

In the process of knowledge management, different stages can be distinguished in which information and further knowledge are processed from data [6]. In the process stages of knowledge management, knowledge is collected, organized, stored, shared, and utilized in a way that improves the decision-making and functioning of the individual and the organization [7]. For example, the activities of state and municipal government generate a wealth of structured data that can be utilized in management and development as we only develop effective processes and practices for processing data into information and further knowledge. However, there are several challenges in knowledge management, due to, for example, technical infrastructure, poor quality data, human bias in thinking, reluctance to share knowledge, or inefficient practices and processes [8]. In addition, the public services which create, and use, the knowledge, are traditionally produced and consumed in 'siloes', where the transparency is often not the first priority [9]. While a long list of challenges can be identified, we can similarly identify the factors that enable knowledge management.

Knowledge management in the context of the public sector has been reasonably studied at both the national $[10,11,12,13]$ and international levels $[14$, $15,16]$, but the vast majority of previous public sector research on knowledge management has focused on only one area of knowledge management at a time, such as the knowledge creation phase, knowledge sharing, or knowledge retrieval. Less often, the different stages of the entire knowledge management process have been illustrated, from knowledge needs to the creation, retrieval, maintenance and sharing of knowledge and its utilization [4]. In order to solve the practical 
challenges that the public organizations face in knowledge management, a holistic view provided by the overall knowledge management process analysis, could offer new insights for development work.

The aim of this paper is to identify the challenges and enablers at different stages of the knowledge management process. The article seeks to answer the empirically weighted research question "What kind of challenges and enabling factors in knowledge management in public sector operations can be identified at different stages of the knowled ge management process model?" The context of the article is the public sector and the research has been conducted through five empirical case studies that represent different kinds of knowledge management development experiments and various public sector organizations. Through the analysis of these diverse cases, the article produces not only a scientific contribution but also a practical contribution from different kinds of development experiments in knowledge management in the public sector.

The structure of the article is as follows: After the introductory chapter, Chapter 2 is followed by a concise theoretical overview of the basics of knowledge management. The main focus of the article is on the presentation of empirical case studies and the analysis of their results, so the theoretical part is followed by Chapter 3, which presents the methodological choices and the carried-out case studies, and Chapter 4, which presents the main results of the case studies. Chapter 5 summarizes the results of the article and contains an evaluation of the study and presents topics for further research.

\section{Knowledge management process}

The purpose of knowledge management is to collect, process, organize, store, share and utilize knowledge in a way that improves the decisionmaking and activities of the individual and the organization [17]. With knowledge management, we can support the organizational problem solving, decision making and strategic development. Indeed, knowledge management is a holistic and systematic process that integrates technology and human a spects [3]. From the perspective of modern public sector operations, knowledge management aims not only to improve the functioning of public sector organizations, but also to provide ways to better understand the needs of citizens and provide them with better and more inclusive services in the most resource-efficient and sustainable way [18, 19].

Knowledge-based approaches, such as knowledge-based value creation, are designed to understand and explain how an organization's internal and external data sources contribute to an organization's competitive advantage [20]. When talking about knowledge management, knowledge refers especially to the result of human activity in decision-making situations. In the digital age, the amount of data and information available is usually no longer an issue [21]. However, organizations need to distinguish what data is relevant, how data and information should be processed to knowledge, how knowledge should be shared within the organization and, where appropriate, to other stakeholders, and how knowledge can be used in decision-making [22, 23, 24].

Knowledge, which is ultimately used in human decision-making and action, is processed from data through information into knowledge by adding structure and meanings to it $[6,23]$. This chain from data to knowledge emphasizes the need for data processing and the nature of enrichment. Thus, knowledge does not appear from scratch, but is created by enriching data and information. Thus, in order to make good, knowledge-based decisions, data and information must be of high quality and easily accessible in a form that is understandable and accessible to decision-makers as timely as possible [25]. To ensure the functioning of this chain, it is necessary to coordinate both the more technical side of knowledge management and the softer, more human side in organizational structures, processes, and practices [17].

Based on previous knowledge management literature Kayworth and Leidner [38] have presented a knowledge management process model that includes the stages of knowledge creation, storage, transfer and application. This model thus offers us a comprehensive starting point for the analysis of the empirical study. However, this model doesn't include the stages of the important questions on how to identify the knowledge needs of the organization and how to measure the success of application of knowledge, These two stages are not included in the model, even though e.g. the relation between performance measurement and knowledge management has been identified as important in earlier studies. In order to overcome this shortage, we elaborate the model further and add to it the relevant aspects of knowledge need identification and measurement from the information management process model presented by Choo [6] in order to gain more holistic analysis tool.

The model begins with the definition of knowledge needs as the first stage of the knowledge management process. The knowledge needs are first identified so that they can later be met as well and efficiently as possible. At this stage, knowledge is obtained both from external sources, such as 
competitors and customers, and from internal sources, such as knowledge systems and communities of practice. The knowledge created and collected from different sources will be organized and maintained in the organization's repositories. This means the stage of a nalyzing and organizing the knowledge, which facilitates the next stages of the process, i.e. the stage of knowledge sharing. However, knowledge only acquires its final meaning when it is used, for example, applied in decisionmaking and operationaldevelopment, and when real changes occur in the organization's operations. Thus, decision-making is here included in one of the important stages of the knowledge management process, namely the utilization/application stage. Furthermore, by measuring and verifying the changes that have taken place and learning from what has happened and thereby identifying new development needs, the cycle starts from the beginning. It should be noted that the process is in fact a very iterative process and that the variation between phases is not always straightforward. The following Figure 1 shows the process model applied in the empirical case study.

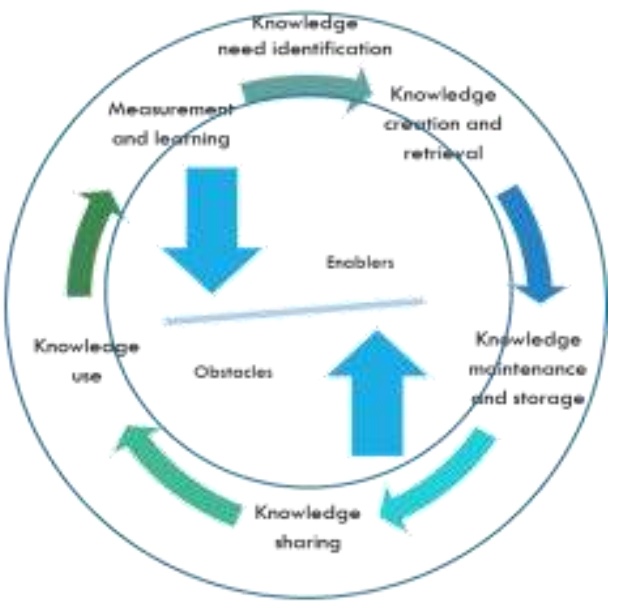

Figure 1. Knowledge management process phases

The process of knowledge management presented above and its various stages include both the more technical side and the softer side of people related to knowledge [4], but the model can be criticized as a mechanistic way to structure as complex a phenomenon as knowledge management actually is. In practice, however, it is often the case that some basic model is needed to identify the challenges of knowledge management and to develop best practices. Nor does applying the process model of knowledge management to practice mean focusing on the process rather than dialogue. On the contrary, dialogue can be better built into organizations when a clear framework is built. The different stages of the process also include both technical and human aspects, so for this reason the model serves as a good analytical tool for identifying the challenges and opportunities of knowledge management [26]. The analysis of the stages of the process model makes it possible to improve the understanding of public sector organizations of their own skills, knowledge and knowledge sources and to support the use of knowledge in problem solving, decision-making and strategic development, as stated in traditional Knowledge Management literature [27, 28, 20].

\section{Method}

We study the obstacles and the enablers of knowledge management through five practical research cases. Cases represent the various stages of the knowledge management process presented in Figure 1. This is a qualitative study, which aims at increased understanding of the phenomenon under scrutiny. Case studies are suitable for studying a complex phenomenon [29] and offer an opportunity for methodological diversity. The case study method was chosen for this study because it allows for the study of a complex phenomenon in the context of real life $[29,30]$. The strengths of the case study are to allow the study of the phenomenon in the natural environment and to develop relevant theory based on an understanding of actual practice [31]. The method is suitable for studying a phenomenon in which the variables are not known and the phenomenon is not yet fully understood. Based on these criteria, the case study is well suited to the empirical study of knowledge management in the public sector.

The five case studies in this article have been selected to represent the different stages of the knowledge management process model. Case studies have utilized data triangulation, so each case produces different perspectives on knowledge management issues. Before the interviews were conducted the researchers familiarized themselves with the documentation regarding the issues and organizations under scrutiny. After having done that the interviewees were selected in co-operation and accordance with the target organizations as they possessed the knowledge on who the most able and suitable respondents were. The development initiatives in the target organizations were in separate stages in their life cycle and none of these were studied during their entirety, but rather a certain period of their duration. The interviewees are from the spectrum of hierarchical level, i.e. from the executive level all the way to the operative personnel. this was deemed necessary in order to 
give the most comprehensive understanding of the phenomenon under study. In all of the cases interviews lasted 45-90 minutes and the interviews were recorded and later on transcribed. In next, each of the cases and their background are briefly opened up.

Case study one $(\mathrm{C} 1)$ represents a large Finnish city that is in the middle of a big change of their managerial system. As an integral part of the managerial system change the city is developing their knowledge management practices as they believe that successful knowledge management processes support the new managerial system and the overall development aims of the city. This case study includes all the phases of the knowledge management process, but especially increases our understanding of the knowledge sharing, use and measurement phases. The case study includes 73 qualitative thematic interviews that were carried out in the fall of 2019.

Case study two (C2) covers a sub-program of the smart city initiative in a large Finnish city. The city's smart city program's sub-program, consisting of various experiments on digitalization aims at ultimately developing digital services to facilitate everyday life for the inhabitants in the future, improve wellbeing and security. The study focuses on the effects and the effectivity of the digitalization experiments aimed at possibilities of scaling the new services to the regular service offering of the city. This case study sheds light especially on the phases of knowledge need identification and knowledge creation in the knowledge management process as the case focuses on the new service development. The semi-structured thematic interviews were conducted during 2018.

Case study three (C3) focuses on the stage of knowledge sharing within the knowledge management process even though it also covers all the other phases of the process. The case study was carried out in time period from the beginning of 2017 to the beginning of 2018. Altogether 26 thematic, qualitative interviews were conducted including both the municipality and the organizational customer perspectives.

Case study four (C4) concentrates mainly on how the gathered knowledge is processed and utilized in decision making processes. The case focuses on revealing the usage of benchmarking, its benefits, challenges, and process in a city's organization. The case contains interviews from representatives of different service areas in the city and from contact persons to various international network associations. The interviewees represent different positions varying from coordinators to the upper management including both corporate executives and political executives. The interviews were semi-structured and conducted between December 2020 and January 2021 virtually in Microsoft Teams. Altogether 30 interviews were carried out.

Case study five (C5) presents benefits and challenges of collaboration and public participation in municipal master plan process. The case focuses on the phases of knowledge sharing, knowledge use and measurement. The case study represents a medium-sized town that has performed and planned a continuous master plan work, which is tightly connected with the town councils working period of four years and the town's own strategy work. In its strategy the town has defined the citizens as the makers of the city and committed in citizen participation and involvement in decision-making to reach the development goals set for the city by 2030 , which includes also the spatial planning of the city [32]. The case concentrates on the third ongoing master plan process and especially to its impact assessment process. Impact assessment takes place on the third year of the master planning process, and on the third ongoing master planning process the town invited also representatives of the third sector organizations in addition to the specialists and city representatives. The third sector organizations representatives were chosen based on a close interest towards the themes. The seminars had six different theme areas with six (6) experts hosting their own theme. The empirical data is presented in Table 1.

Table 1. Empirical data

\begin{tabular}{|c|c|c|}
\hline $\begin{array}{l}\text { Case } \\
\text { study }\end{array}$ & Interviews & Additional material \\
\hline $\mathrm{C} 1$ & 73 & City strategy documents \\
\hline $\mathrm{C} 2$ & 20 & $\begin{array}{l}\text { Documentation of the city (e.g. } \\
\text { strategy, program doc's) }\end{array}$ \\
\hline $\mathrm{C} 3$ & 26 & $\begin{array}{l}\text { Data reports from the new } \\
\text { developed digital system }\end{array}$ \\
\hline $\mathrm{C} 4$ & 30 & Workshop materials \\
\hline $\mathrm{C} 5$ & 7 & $\begin{array}{l}\text { Observation data from two impact } \\
\text { assessment seminars } \\
\text { Documentation including the } \\
\text { master plan draft, statements }(15) \\
\text { and opinions (80) for the draft }\end{array}$ \\
\hline
\end{tabular}


The interview materials of the case studies analyzed with content analysis [30] by multiple researchers that form the author team of this paper. Each of the five cases had a responsible researcher from the author team. The responsible researcher coded all the full empirical materials of the responsible case(s). The basic coding frame was the knowledge management process model stages. After coding each of the case data sets, the research team ordered and aggregated to higher levels of analysis together in collaboration in order to provide holistic view and interaction between the cases and the knowledge management process model used as the analysis tool.

\section{Empirical results}

In case study one the bigger change of management system affected the need to develop knowledge management in many ways. As mayor had become the leader of the city and he had set a new institution of the so-called mayor's office, there occurred almost an unlimited need for knowledge among the mayor's staff. The interviewees felt that it was in overall a good thing, but it also came with challenges.

First of all, the overall decision-making and preparation cycle had accelerated. This acceleration required also fast knowledge management process and sometimes the information and knowledge did not flow well enough. The interviewees stated that this obstacle may had been caused by the lack of appropriate skills of the personnel, but also because they were overloaded, and they didn't have enough time for sharing knowledge. Secondly, the empirical data also revealed that knowledge about the whole was scattered and for this reason it was very difficult to use. Instead of overall understanding and holistic knowledge the city had branch specific knowledge management and development of knowledge management practices. Thirdly, there were pretty weak resources for the development of knowledge management processes even though it was stated as one of the key development areas by the mayor's office. The interviewees brought up their wish of developing knowledge management more at strategic level. Fourthly, the digitalization process that was also under way in the city was emphasizing more on the ICT side, but not so much in other areas, such as in practical work and really in knowledge management processes. The interviewees mentioned that a new attitude was born in the city to favor digital solutions, but it still appeared as a fragmented, unmanaged and uncoordinated development in stea d of unified and controlled development. They suggested as one solution to invest in the know-how of digitalization of the city personnel. Fifthly, the empirical data opened up the challenges in knowledge sharing. The disadvantage of the overall development was the ambiguity of guidance as there was guidance from many sources, e.g. the mayorhad direct discussions with branch managers past the department heads and past branch managers. Respectively political assistant meetings are held in secret, and the mayor sets up teams whose existence or role others do not know. All of these human factors created challenges in effective knowledge sharing and in overall knowledge management process.

Case study two shows that co-operation between all involved parties is required in order to be successful in implementing a novel culture that is required for implementing new ways of working in the traditionally not overly flexible public sector. The newer ways of working may mean to express the knowledge needs more clearly and thus expediate the processes by using modern technologies and innovations therein. The change in the attitudes, and later the culture, is a significant factor in either promoting the knowledge-based approach or alternatively dismissing it. Similarly, the initiative will benefit from a well-proportioned communications and co-operation with this sector as it is a fundament in change management under any circumstances.

To succeed in this, one needs to gather intel from the target audience, for example, when contacting the customer service of the city. Similarly, the waiting times may be reduced, thus freeing the civil servants' time to something more meaningful work tasks.

In case study three there is a lot of regulated knowledge involved in construction that should be as easily accessible as possible when making building permit decisions and supervising the construction process. An important role is also played by the possibility of sharing knowledge between different authorities and between the authorities and a wide customer base. Data sharing has traditionally been associated with many challenges, such as storing data in scattered separate systems and physical paper archives. The slowness and opacity of the permitting process towards the customer has also been a challenge. To address these problems at the national level, the need for the development of an integrated digital system was seen. It was decided to develop the system using joint development methods between the municipalities and the company responsible for developing the system.

As a result of the co-development process, it was possible to build a functioning digital system 
where all applications for building permits can be processed and information can be easily shared between different actors. The end result was a functioning system that in itself already supports knowledge sharing. However, in addition to this technical aspect, the system was also able to build important practices from a human point of view to support knowledge sharing. The communication activities of the company responsible for developing the system succeeded in building an active community around the digital system, including various events for municipal officials, regular meetings and a communication channel for liaison officers appointed by the municipality. Liaison officers, for example, were rewarded for their activism in community activities and this created a positive atmosphere of success. All these activities strengthened the community built around the digital system, which in the first phase consisted of representatives of the municipality. In addition to the community, the interviewees also appreciated the informative website and chat service. They also stressed the importance of extending the user group to national authorities, such as regional agencies.

Building inspectors, designers and customer service staff are the most people in the municipalities who use the digital system. Based on the interviews, they felt that the sharing of knowledge was greatly facilitated in their mutual work, but also in the interaction with customers.

The challenges related to the digital system were seen as the different rules, instructions and practices of different municipalities for the management of permitting processes. For example, one municipality only accepted processing in the digital system, while several others used both the traditional paper process and the new digital process at the same time. According to the interviewees, these lack of common rules and regulations related to the process posed challenges, as regulations and practices can vary even within a municipality depending on the industry. This brought challenges to knowledge sharing, but also added challenges to other stages of the process. In case three, therefore, the challenges of knowledge sharing emerged, but the challenges of this phase also affected other phases of the knowledge management process. Again, the sharing of knowledge was challenged by the boundaries between different organizations, but also by different policies and practices (human perspective) and incompatible information systems (technical perspective).

Benchmarking and the knowledge received from it, should be at its best, not only of high-quality in content but also accessible, understandable and usable at the right time for decision-makers. The case study four reveals that systematic practices are needed for the knowledge gathering, maintenance and storage to achieve better utilisation of benchmarking in decision making. The city's benchmark activities should have common outlines and goals, where the usage of knowledge and benchmarking activities are more strategic and systematic and also measured according to shared impacts. The implementing, documentation and sharing of knowledge in the organization was considered difficult and developing this is vital to improving the flow of information. Currently the distribution of knowledge is considered unbalanced and sporadic. To secure the chain of knowledge from benchmarking to decision makers, the technical side (like software systems for knowledge storage) and the softer, human side needs to be adapted and matched together.

Case study five focuses on public participation in an impact assessment process. It can be said that the impact assessment process itself was considered a good thing and this had value as itself, but that it still needs developing. The impact assessment process is a mandatory part of master planning and its legitimacy was understood by various stakeholders, however the perception of how significant the impact of their participation and knowledge was, varied among the stakeholders and experts involved. The interviewees stated that the seminars were meaningful and that the participants could openly express their opinions and views. However, inequality in communication and information and knowledge sharing to the participants, created experiences of discontent, injustice and evoked to a feeling of apparent possibility to influence. Increasing awareness of communication, adequate, timely and equal communication and distribution of knowledge during the process are crucial elements in creating a supportive and engaging participation. Furthermore, implementing a knowledge sharing supporting culture, and designing and redesigning the process constantly together with various participating stakeholders helps to a chieve functional process.

\section{Discussion and conclusions}

Making the knowledge management process to work requires seamless cooperation between the technical infrastructure and human factors, so that knowledge management can truly create value for public administration actors and citizens [4].

Much of the previous public sector knowledge management research has focused on issues related to either information systems, data quality, or 
specific aspect of knowledge management. Less frequently, the various stages of the entire knowledge management process have been illustrated, from information needs to information acquisition, analysis and sharing, and its utilization. In this article, we have sought to look at this whole process of knowledge processing and, through five case studies, have identified concrete challenges that the public sector faces in knowledge management. We sought to verify the mentioned stages from the process model by scrutinizing the findings from the cases. We came up with a number of factors affecting the knowledge management process in the public sector organizations, both supporting the actions and the decision-making and resisting or even hindering them. We have identified these key factors that enable successful knowledge management in the public sector as a synthesis of the five empirical cases. The main obstacles and enablers are illustrated in next Table 2.

Table 2. Key empirical findings

\begin{tabular}{|c|c|c|}
\hline $\begin{array}{l}\text { KM } \\
\text { process } \\
\text { phase }\end{array}$ & Obstacle & Enabler \\
\hline $\begin{array}{l}\text { Knowledge } \\
\text { need } \\
\text { identification }\end{array}$ & $\begin{array}{l}\text { Lack of shared } \\
\text { vision and aims } \\
\text { 'Siloed'operation. } \\
\text { Short- } \\
\text { sightedness, } \\
\text { narrow-scope in } \\
\text { observation } \\
\text { Lack of } \\
\text { communication }\end{array}$ & $\begin{array}{l}\text { Enhanced, } \\
\text { planned } \\
\text { communication } \\
\text { Widened scope of } \\
\text { preliminary } \\
\text { analysis }\end{array}$ \\
\hline $\begin{array}{l}\text { Knowledge } \\
\text { retrieval and } \\
\text { creation }\end{array}$ & $\begin{array}{l}\text { Organizational } \\
\text { boundaries } \\
\text { Limited resources } \\
\text { Varying } \\
\text { objectives } \\
\text { Abundance of } \\
\text { data } \\
\text { Incompatible data } \\
\text { Inadequate } \\
\text { tools/technology }\end{array}$ & $\begin{array}{l}\text { Setting common } \\
\text { goals } \\
\text { Clarifying the } \\
\text { mutual setting } \\
\text { Communication } \\
\text { Policies and } \\
\text { practices }\end{array}$ \\
\hline $\begin{array}{l}\text { Knowledge } \\
\text { maintenance } \\
\text { and storage }\end{array}$ & $\begin{array}{l}\text { Differing, } \\
\text { incompatible } \\
\text { systems } \\
\text { Array } \\
\text { methods, of } \\
\text { technologies and }\end{array}$ & $\begin{array}{l}\text { Better overview } \\
\text { Improved } \\
\text { communication } \\
\text { Shared outlines } \\
\text { for operation } \\
\text { More efficiently }\end{array}$ \\
\hline
\end{tabular}

\begin{tabular}{|c|c|c|}
\hline & $\begin{array}{l}\text { tools Lack of } \\
\text { digital skills }\end{array}$ & $\begin{array}{l}\text { allocated and } \\
\text { improved } \\
\text { resources }\end{array}$ \\
\hline $\begin{array}{l}\text { Knowledge } \\
\text { sharing }\end{array}$ & $\begin{array}{l}\text { Organizational } \\
\text { boundaries } \\
\text { Distrust } \\
\text { Lack of time } \\
\text { Power asymmetry } \\
\text { and inequality } \\
\text { Unequal } \\
\text { distribution of } \\
\text { knowledge }\end{array}$ & $\begin{array}{l}\text { Improved culture } \\
\text { Wider big picture } \\
\text { Situation analysis } \\
\text { Recognition and } \\
\text { acknowledgement } \\
\text { of needs of others }\end{array}$ \\
\hline $\begin{array}{l}\text { Knowledge } \\
\text { use }\end{array}$ & $\begin{array}{l}\text { Change resistance } \\
\text { Scattered } \\
\text { knowledge } \\
\text { Unfitting } \\
\text { knowledge } \\
\text { products }\end{array}$ & $\begin{array}{l}\text { Improved } \\
\text { organizational } \\
\text { culture } \\
\text { Better designed } \\
\text { and redesigned } \\
\text { knowledge } \\
\text { products } \\
\text { Incrementally } \\
\text { iterated } \\
\text { knowledge } \\
\text { process }\end{array}$ \\
\hline $\begin{array}{l}\text { Mea surement } \\
\text { and learning }\end{array}$ & $\begin{array}{l}\text { Organizational } \\
\text { boundaries } \\
\text { Part- } \\
\text { optimalization } \\
\text { Lack of } \\
\text { communication }\end{array}$ & $\begin{array}{l}\text { Transparency, big } \\
\text { picture } \\
\text { Well-justified } \\
\text { measures } \\
\text { Visibility } \\
\text { operation } \\
\text { Change } \\
\text { operational } \\
\text { culture towards } \\
\text { continuous } \\
\text { learning }\end{array}$ \\
\hline
\end{tabular}

Our research validates, through empirical research, many of the practical challenges of knowledge management identified in the previous literature. Especially in knowledge sharing phase the empirical findings from the public sector are rather similar than expressed in general knowledge sharing challenges literature [33, 34], such as including lack of time and lack of trust as the main challenges. However, we have also identified the factors that enable successful knowledge management and thus serve, at least in part, as solutions to the challenges identified. The approach provides valuable insights for decision-making management and creates an understanding of knowledge-based value creation. For example, in the case four the implementing a 
knowledge sharing supporting culture, and designing and redesigning the process constantly together with various participating stakeholders helped to achieve functional process [35]. Furthermore, in the case three the main enabler of knowledge management emerged through the digital system created as a result of co-development process. This made it possible to remove the boundaries of access to knowledge between different units and different municipalities. However, this digital system alone would not have been able to guarantee successful knowledge management, but an important enabler was the community processes and events created during the co-development process that supported human interaction. Without consideration of human factors, knowledge cannot be shared, as the digital system ultimately only supports the sharing of data and information. The understanding of these identified enablers provides relevant information to those public sector organizations that use or have plans to make more use of knowledge management to develop their own operations.

This article provided an overview of knowledge management in the public sector through five different cases. The case studies were carried out to provide an understanding of the different stages of the knowledge management process model in the public sector. As the case studies were all from Finland, this has a limiting effect on the depth of the results of this study. Specific context limits the case findings, which affects the generalizability of the study results.

The cases have brought different, but still very limited, perspectives on knowledge management. Further research is still needed on this topic. Earlier knowledge management literature has stated that the implementation of knowledge management practices may be a more demanding task in public sector organizations because of their more bureaucratic modus operandi and effect of political steering policies than in the private sector [36] and has proposed more empirical and especially qualitative investigations on policy issues affecting knowledge management in public sector organizations [37]. These kinds of effects of bureaucracy and political guidance need still further analysis. Within the rich empirical data set at hand in this paper there were weak signals of these kinds of effects, but it still need more comprehensive analysis.

Furthermore, there are still a very limited number of reported user experiences with new knowledge management tools available. Sharing such user experiences, both in terms of challenges and successes, would be necessary to increase the courage the different public sector organizations to experiment with different tools of knowledge management. However, it would be at least as important to raise a debate on the issues of principle, such as policies, rules of the game, and processes, that should change to enable genuine knowledge management. Moreover, it should always be borne in mind that knowledge management is not an end in itself, but only a tool - the goal is to create value together and sustainably better than before.

\section{Acknowledgements}

This research was supported by the Strategic Research Council's Project CORE (313013 +313016 ).

\section{References}

[1] Chang, C. L. H., \& Lin, T. C. (2015). The role of organizationalculture in the knowledge management process. Journal of Knowledge management, 19 (3), pp. 433-455.

[2] Nonaka, I., \& Toyama, R. (2007). Strategic mana gement as distributed practical wisdom (phronesis). Industrial and corporate change, 16(3), 371-394.

[3] Valkokari, K., Helander, N., (2007). Knowledge management in different types of strategic SME networks. Management Research News: Communication news of emergent international management research, 30, 597608.

[4] Jääskeläinen, A., Sillanpää, V., \& Helander, N. (2019). A model for profiling information and knowledge management in the public sector. In Proceedings of 14th IFKAD 2019 conference: Matera, Italy, 5-7 June.

(Proceedings IFKAD).

[5] Girard, J.P. \& Girard, J.L. (2015). Defining knowledge management: Toward an applied compendium, Online Journal of Applied Knowledge Management.3(1), 1-20.

[6] Choo, C.W., (2002). Information management for the intelligent organization: the art of scanning the environment. Information Today, Inc.

[7] Vitt, E., Luckevich, E., Misner, S., (2002). Business intelligence: making better decisions faster. Microsoft Press Redmond, 
WA.

[8] Väyrynen, H., Helander, N., \& Vasell, T. (2017). Knowledge management foropen innovation: comparing research results between SMEs and large companies. International Journal of Innovation Management, 21(05), 1740004.

[9] Hellsten, P. \& Pekkola, S. (2020). Impacts of Digitalization: Many Agendas on Different Levels. Proceedings of the 53rd Hawaii International Conference on System Sciences (HICSS), Jan 7 - 10, 2020, Maui, Hawaii.

[10] Leskelä, R. L., Haa visto, I., Jää skelä inen, A., Sillanpää, V., Helander, N., Laa sonen, V., ... \& Torkki, P. (2019). Tietojohtaminen ja sen kehittäminen: tietojohtamisen arviointimalli ja suosituksia maakuntavalmistelun pohjalta. (In Finnish)

[11] Laa sonen, V., Antikainen, J., Ha anpää, S., Aro, T., Salminen, V., Järvelin, A. M., ... \& Huovari, J. (2018). Tiedolla johtaminen a luekehittämisessä-ehdotus aluekehityksen tilannekuvaviitekehykseksija mittaristoksi. (In Finnish)

[12] Kolehmainen, J., Irvine, J., Stewart, L., Karacsonyi,Z., Szabó, T., Alarinta, J., \& Norberg, A. (2016). Quadruple helix, innovation and the knowledge-based development: Lessons from remote, rural and less-fa voured regions. Journal of the Knowledge Economy, 7(1), 23-42.(In Finnish)

[13] Jalonen, H. (2015). Tiedolla johtamisen näyttämö ja kulissit. Virtanen, P., Stenvall, J. \& Rannisto,PH.( eds.) Tiedolla johtaminen julkishallinnossa. Teoriaa ja käytäntöjä. Tampere, Tampereen Yliopistopaino Oy, 4068. (In Finnish)

[14] Harvey, G., Skelcher, C., Spencer, E., Jas, P., \& Walshe, K. (2010). Absorptive capacity in a non-market environment: A knowledgebased approach to analysing the performance of sector organizations. Public Management Review, 12(1), 77-97.

[15] Ovalle, M. D. R. G., Márquez, J. A. A., \& Salomón, S. D. M. (2004). A compilation of resources on knowledge cities and knowledge-based development. Journal of knowledge management.

[16] Cong, X., \& Pandya, K. V. (2003). Issues of knowledge management in the public sector. Electronic journal of knowledge management, 1(2), 25-33.

[17] Jääskeläinen, A., Sillanpää, V., Helander, N., Leskelä, R. L., Ha a visto, I., Laa sonen, V., \& Torkki, P. (2020). Designing a maturity model for analyzing information and knowledge management in the public sector. VINE Journal of Information and Knowledge Management Systems.

[18] Amayah, A. T. (2013). Determinants of knowledge sharing in a public sector organization. Journal of knowledge management, 17 (03), pp. 454-471.

[19] Syed-Ikhsan, S.O.S. \& Rowland, F. (2004), Knowledge management in a public organization: a study on the relationship between organizationalelements and the performance of knowledge transfer. Journal of Knowledge Management, 8 (2), pp. 95111.

[20] Grant, R.M., (1996). Toward a knowledge-based theory of the firm. Strategic Management Journal, 17, 109-122.

[21] Chen, H., Chiang, R.H., Storey, V.C., (2012). Business intelligence and analytics: From big data to big impact. MIS Q. 36.

[22] Kaivo-oja, J., Virtanen, P., Jalonen, H., Stenvall, J., (2015). The effects of Internet of Things and Big Data to organizations and their knowledge management practices. Knowledge Management in Organizations Lecture Note in Business Information Processing, 224, 495-513.

[23] Thierauf, R.J., (2001). Effective business intelligence systems. Greenwood Publishing Group.

[24] Choo, C.W., (1998). The Knowing Organization: How Organizations Use Information to Construct Meaning, Create Knowledge, and Make Decisions. New York: Oxford University Press.

[25] Vilminko-Heikkinen, R., Pekkola, S., (2017). 
Master data management and its organizationalimplementation: An ethnographicalstudy within the public sector. Journal of Enterprise Information Management, 30 454-475.

[26] Hellsten, P. \& Myllärniemi, J. (2019). Business Intelligence Process Model Revisited., in: Proceedings of the InternationalConference on Knowledge Management and Information Systems (KMIS), KMIS.

[27] Dalkir, K., (2013). Knowledge management in theory and practice. Routledge.

[28] Hislop, D., (2013). Knowledge management in organizations: A critical introduction. Oxford University Press, New York.

[29] Yin, R.K. (2003). Case study research : design and methods. Sage Publications.

[30] Saunders, M., Lewis, P., Thornhill, A. (2009). Research methods for business students. Prentice Hall.

[31] Voss, C., Tsikriktsis, N., Frohlich, M. (2002) Case research in operations management, Int. J. Oper. Prod. Manag., vol. 22, no. 2, pp. 195-219.

[32] Tuomisaari, J. (2019). Epävarmuuden edessä: kuntien strateginen kaa voitus jousta vana käytäntönä. Tampereen yliopisto. (In Finnish)

[28] Hislop, D., (2013). Knowledge management in organizations: A critical introduction. Oxford University Press, New York.

[29] R. K. Yin, Case study research : design and methods. Sage Publications, 2003.

[30] M. N. K. Saunders, P. Lewis, and A. Thornhill, Research methods for business students. Prentice Hall, 2009.

[31] C. Voss, N. Tsikriktsis, and M. Frohlich, "Case research in operations mana gement," Int. J. Oper. Prod. Manag., vol. 22, no. 2, pp. 195219, Feb. 2002.

[32] Tuomisaari, J. (2019). Epävarmuuden edessä: kuntien strateginen kaavoitus jousta vana käytäntönä. Tampereen yliopisto. (In Finnish)

[33] Riege, A. (2005). Three-dozen knowledge-sharing barriers managers must consider. Journal of knowledge management, 9, $18-35$.

[34] Vuori, V., Helander, N., Mäenpää, S. (2018). Network level knowledge sharing: Leveraging Riege's model of knowledge barriers. Knowledge Management Research \& Practice.

[35] Paunu, A., Pansio, J., Käpylä, J., Helander, N., 2020. Challenges in Public Participation and Collaboration: A Case Study in Finnish EnvironmentalDecision-making. Proceedings of the 12th International Joint Conference on Knowledge Discovery, Knowledge Engineering and Knowledge Management: Volume 3: KMIS. Salgado, A., Bernardino, J. \& Filipe, J. (eds.). SCITEPRESS, Vol. 3. p. 172-179

[36] Chong, S. C., Salleh, K., Ahmad, S. N. S., Sharifuddin, S. I. S. O. (2011). KM implementation in a public sector accounting organization: an empirical investigation. Journal of Knowledge Management, 15:3, pp. 497-512.

[37] Riege, A. \& Lindsay, N. (2006). Knowledge management in the public sector: stakeholder partnerships in the public policy development. Journal of Knowledge Management, 10:3,pp. 24-39.

[38] Kayworth, T. \& Leidner, D. (2003), "Organizational culture as a knowledge resource", in Holsapple, C.W. (Ed.), Handbook on Knowledge Management, Volume 1: Knowledge Matters, SpringerVerlag, Heidelberg, pp. 235-252. 